'A Jamiy: Jurnal Bahasa dan Sastra Arab

Available Online at http://journal.umgo.ac.id/index.php/AJamiy

Volume 10 , No. 1, Juni 2021, 29-46

DOI: http://dx.doi.org/10.31314/ajamiy.9.2.29-46.2021

\title{
Model Pembelajaran Teams Games Turnament (TGT) Sebagai Alternatif Pembelajaran Maharah Kitabah
}

\author{
Muhammad Anas ${ }^{1}$, Muassomah ${ }^{2}$ \\ 1,2, Universitas Islam Negeri Maulana Malik Ibrahim Malang, Indonesia \\ Email: muhammadanas1119@gmail.com,muassomah@bsa.uin-malang.ac.id
}

Received: 2021-01-03 Revised: 2021-06-07 Accepted:2021-06-24

\begin{abstract}
This research aims to analyze student needs and problems and provide alternative learning models that can increase students' interest in participating in learning, provide opportunities for students to hone their writing skills and overcome differences in student backgrounds. This research uses a qualitative method that aims to explore information and data in the field related to the problems faced by students in learning to write. The data of this research were collected from Arabic students and teachers as well as parties related to learning Arabic by means of observation, interviews and documentation. The results of this study show that there is a suitability regarding the problems faced by Sabilurrasyad Islamic Junior High School students when applying the Teams Games Tournament (TGT) type cooperative learning model as an effort to overcome the problem.
\end{abstract}

Keyword: Writing Skills. Cooperative Learning Model Type Teams Games Tournament (TGT), Interest To Learn

\begin{abstract}
Abstrak
Penelitian ini bertujuan menganalis kebutuhan siswa dan masalah yang dihadapinya serta memberikan alternatif model pembelajaran yang dapat meningkatkan antusiasme siswa dalam mengikuti pembelajaran, memberikan kesempatan siswa dalam mengasah kemampuan Maharah Kitabah serta mengatasi perbedaan latar belakang siswa dan kemampuannya terkait kitabah. Penelitian ini menggunakan metode kualitatif yang bertujuan untuk menggali informasi dan data di lapangan terkait masalah yang dihadapi siswa dalam pembelajaran kitabah. Data penelitian ini digali dari siswa dan guru bahasa

'A Jami Jurnal Bahasa dan Sastra Arab

ISSN: 2252-9926 (Print), ISSN: 2657-2206 (Online)


Arab serta pihak-pihak yang terkait dengan pembelajaran bahasa Arab dengan cara observasi, wawancara dan dokumentasi. Hasil penelitian ini memperlihatkan adanya kesesuaian terkait masalah yang dihadapi siswa SMP Islam Sabilurrasyad apabila menerapkan model pembelajaran kooperatif tipe Teams Games Turnament (TGT) sebagai upaya untuk mengatasi masalah yang sedang dihadapi.

Kata kunci: Maharah Kitabah, Model Pembelajaran Kooperatif Tipe Teams Games Turnament (TGT), Minat Belajar

\section{A. Pendahuluan}

Pembelajaran merupakan bentuk interaksi antara guru dan siswa. Seorang guru yang menjadi seorang pendidik memberikan instruksi kepada siswa sebagai peserta didik agar dapat memeperoleh pengatahuan melalui proses pembelajaran. Banyak cara yang dapat dilakukan seorang pendidik dalam berinteraksi dengan peserta didik dan sumber belajar pada proses pembelajaran, hal ini karena peserta didik memiliki karakteristik yang beragam dalam membangun sebuah pengatuhuan dari informasi yang telah didapatkannya ${ }^{1}$. Namun pada realitanya banyak guru di sekolah yang masih menggunakan cara-cara konvensional serta monoton ketika menyampaikan pengetahuan kepada siswa sehingga tidak semua siswa mampu memperoleh pengetahuan yang disampaikan oleh guru. Bahkan terkadang terdapat pula seorang guru yang memyampaikan pengetahuan yang terdapat pada materi pelajaran yang berbeda-beda dengan satu metode atau strategi yang sama, karena kurangnya inovasi dan pemahaman para guru dalam melakukan penyampaian, sehingga menyebabkan proses pembelajaran kurang efektif dan membosankan serta hasil belajar tidak seperti yang diharapkan. ${ }^{2}$

Pembelajaran yang efektif apabila kegiatan mengajar dapat mencapai tujuan sesuai pada perencanaan awal. Pembelajaran dikatakan efektif ketika peserta didik dapat menyerap materi pelajaran dan efisien. ${ }^{3}$ Pembelajaran yang efektif tentu tidak dapat diperoleh dengan suasana belajar yang

1 Anis Purwitasari, Keterampilan Guru Dalam memilih Strategi Pembelajaran Yang Sesuai Dengan Gaya Belajar Siswa Di MIM PK Kartasura, Naskah Publikasi Skripsi, (Surakarta: Universitas Muhammadiyah Surakarta, 2019), h. 2.

2 Bunga Chika Pratama, Model Pembelajaran Two Stay Two Stray Berbantu Media Puzzle Terhadap Hasil Belajar Di Tinjau Dari Gaya Belajar Siswa Jurnal Penelitian dan Pengembangan Pendidikan. Vol. 3 (2) pp. 84-88, (Semarang :PGSD, Universitas PGRI Semarang,2019), h. 85.

3 Mulyono, Strategi Pembelajaran, (Malang : UIN-Maliki Press, 2012), cet. Ke-2, h.vii

\section{'A Jami Jurnal Bahasa dan Sastra Arab}


membosankan dengan penggunanan metode dan strategi pembelajaran yang dilakukan seccara terus-menerus tanpa adanya variasi. Hal ini karena penggunaan metode yang bervarasi akan meningkatkan ketertarikan siswa dalam mengikuti pembelajaran dan menjadikan suasana belajar akan lebih hidup. ${ }^{4}$

Begitu pula pada pembelajaran Kitabah yang merupakan salah satu dari empat keterampilan berbahasa yaitu Istima', Kalam, Qiro'ah dan Kitabah. Maharah kitabah merupakan keterampilan dan kemampuan berbahasa yang cukup sulit karena dengan menulis seseorang harus menerapkan dua kemampuan secara bersamaan, kemampuan tersebut yaitu kemampuan bersifat teknis dan produktif ${ }^{5}$. Kemampuan teknis adalah kemampuan untuk menuangkan tulisan bahasa Arab dengan baik dan benar, yang itu meliputi penggunaan tanda baca (alamat altarqim), penggunaan kaidah bahasa (qowaid) dan kebenaran tulisan (imla'). ${ }^{6} \mathrm{Hal}$ ini menjadikan siswa merasa bosan dan kurang antusias untuk mengikuti pembelajaran ditambah lagi jika seorang guru hanya menggunakan satu model pembelajaran saja dan kurang adanya motivasi dalam menggunakan model-model lainnya yang dapat digunakan dalam pembelajaran maharah kitabah.

Salah satu cara yang biasa digunakan untuk merealisasikan proses pembelajaran menjadi kegiatan yang menyenangkan adalah dengan menggunakan metode Teams Games Turnament (TGT). Teams Games Turnaments merupakan pembelajaran yang beraliran kepada model pembelajaran kooperatif yang memiliki ciri khusus yaitu dilakukan dengan sistem kelompok dengan penyampaian dalam bentuk permainan-permainan akademik, adapun kelompok adalah terdiri dari semua siswa yang sedang mengikuti pembelajaran dengan tanpa membedakan latar belakang siswa. ${ }^{7}$

SMP Islam Sabilurrasyad Malang merupakan salah satu sekolah yang memberikan pembelajaran bahasa Arab kepada siswa-siswinya. Sekolah ini memiliki ciri khas sebagai sekolah yang berbasis pesantren. Pada kesehariannya

4 Slameto, Belajar dan Faktor - Faktor Belajar yang Mempengaruhi, (Jakarta: Rineka Cipta, 1995) h. 94.

5 Umamah, M., \& Muassomah, M. Pembelajaran Daring Melalui Teknik Kolaboratif pada Keterampilan Menulis Peserta didik di SMA Darul Qur'an Kota Mojokerto. ALSUNIYAT: Jurnal Penelitian Bahasa, Sastra, dan Budaya Arab, 3(2), 88-100.

6 Abdul Hamid, Mengukur Kemampuan Bahasa Arab untuk Studi Islam, (Malang: UIN Maliki Press, 2013), h. 74.

7 Agus suprijono, Cooperative Learning Teori \& Aplikasi PAIKEM(Yogyakarta: Pustaka Pelajar, 2011), h. 58.

\section{'A Jami Jurnal Bahasa dan Sastra Arab}


selain siswa-siswi belajar pada sekolah formal, mereka juga belajar bahasa Arab di Madrasah Diniyah. Namun pembelajaran pada sekolah ini masih identik dan kerab menggunakan metode ceramah dengan strategi Qowaid wa Tarjamah baik ketika pembelajaran formal di sekolah atau di Madrasah Diniyah. Hal ini menjadikan siswa-siswi merasa bosan dan kurang bersemangat untuk mengikuti pembelajaran bahasa Arab. selain itu penggunaan metode ceramah dengan strategi Qowaid wa Tarjamah menjadikan siswa sulit untuk menguasai Maharah Kitabah dikarenakan kurangnya aplikasi dan praktek selama mengikuti pembelajaran. Atas dasar ini penliti akan membahas terkait alternatif model pembelajaran apa yang tepat digunakan untuk mengatasi permasalahan kurangnya kemampuan maharah kitabah di SMP Islam Sabilurrasyad Malang?

\section{B. Pembahasan dan Hasil Penelitian}

\section{Kemahiran Kitabah}

Aktivitas menulis merupakan kemampuan berbahasa paling akhir setelah ketrampilan berbahasa lainya. Jika dibagi sesuai dengan tingkatannya maka urutan dari ketrampilan bahasa adalah menyimak, berbicara, membaca, dan menulis yang masing-masing berkaitan erat. Urutan ini diilhami dari gambaran anak kecil yang menempuh tahapan-tahapan perkembangannya ${ }^{8}$.

Banyak dari pembelajar bahasa yang menganggap menulis merupakan ketrampilan yang sulit dari pada ketrampilan yang lainya. Hal ini disebabkan karena dalam menulis perlu untuk menguasi berbagai unsur kebahasaan yang menjadi isi tulisan, sehingga menjadi tulisan yang runtut dan padu. Secara istilah maharah kitabah adalah kemampuan dalam medeskripsikan atau mengungkapkan isi pikiran, mulai dari aspek yang sederhana seperti menulis kata-kata sampai kepada aspek yang komplek yaitu mengarang. ${ }^{9} \quad$ Pengertian kitabah menurut bahasa adalah kumpulan makna yang tersusun dan teratur. Dan makna kitabah secara epistimologi adalah kumpulan dari kata yang tersusun dan mengandung arti, karena kitabah tidak akan terbentuk kecuali dengan adanya kata yang beraturan dan dengan adanya tulisan manusia bisa menuangkan ekspresi hatinya dengan bebas sesuai denganapa yang difikirkannya. Dengan menuangkan

8 Dwi Cahyadi Wibowo, Aspek-Aspek keterampilan dalam pendidikan bahasa, http:// DWI CAHYADI WIBOWO: aspek-aspek keterampilan dalam pendidikan bahasa

${ }^{9}$ Acep Hermawan, Metodologi Pembelajaran Bahasa Arab, (Cct IV; Bandung: PT Remaja Rosdakarya, 2014) h. 151.

\section{'A Jami Jurnal Bahasa dan Sastra Arab}

ISSN: 2252-9926 (Print), ISSN: 2657-2206 (Online) 
ungkapan yang tertulis diharapkan para pembaca dapat mengerti apa yang ingin penulis ungkapkan. ${ }^{10}$

\section{a. Pembagian tahapan maharah kitabah}

Dalam pembelajaran bahasa arab, secara garis besar maharah kitabah dibagi menjadi tiga kategori tahapan yaitu imla', khat dan insya'. Menurut Ainun Rosyidah dan Abdul Basid (dalam Wafa) menjabarkan tahapan yang perlu diperhatikan siswa dalam pembelajaran maharah kitabah meliputi: a) mencontoh, sebagai tahapan awal untuk mengenal materi secara praktik, b) reproduksi, dengan menulis apa yang dipelajari secara lisan, c) imla', praktik dengan menulis apa yang didengar, sehingga selain kemampuan mendengar, menyimak dengan cermat juga sangat diperlukan untuk mengetahui sejauh mana pemahaman yang ditangkap, d) rekombinasi dan transformasi, latihan menggabungkan kata sesuai kaidah nahwiyah dan mengubah bentuk kalimat sesuai dengan kaidah nahwiyah dan shorfiyah, e) mengarang terpimpin, latihan menulis yang mulai terarah, f) mengarang bebas, dalam tahap ini siswa mulai dilatih untuk mengutarahkan ide/pikiran/gagasan yang ada didalam hati, dengan tetap dalam bimbingan pengajar. $^{11}$

Pendapat ini ditegaskan oleh Rusydi, yaitu ketrampilan dasar yang perlu diperhatikan oleh siswa dalam pembelajaran ketrampilan maharah kitabah antara lain: a) berkaitan dengan teknis penulisan Arab; menulis dari kanan ke kiri, mengenal tanda baca dan fungsi, menulis dengan benar sesuai kaidah imla', b) berkaitan dengan penguasaan karakter tulisan Arab; mengetahui kaidah imla; jenis khat, karakter tulisan arab seperti mad, tanwin, ta' marbuthah dan cermat dengan tulisan sambung atau tidak serta huruf-huruf yang tidak terbaca, c) berkaitan dengan kegiatan dan area menulis, meringkas, menulis berbagai macam surat, memperkaya mufradat dan struktur kalimat, mendiskripsikan, menulis laporan dan biodata dalam formulir. ${ }^{12}$

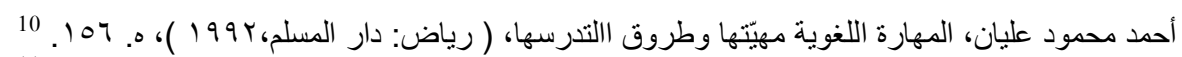

11 Ahris Choiri Wafa, Problematika Pembelajaran Maharah al-Kitabah Siswa Kelas X MAN Tempel Sleman, ( Yogyakarta, 2004), h. 15-17

12 Ainun Rosyidah dan Abdul Basid, Analisis Diagnostik Kesulitan Belajar Maharah alKitabah Mahasiswa Jurusan Bahasa dan Sastra Arab Angkatan 2015 UIN Maulana Malik Ibrahim Malang, ( Malang, 2017), h. 96-97.

\section{'A Jami Jurnal Bahasa dan Sastra Arab}




\section{b. Masalah dalam menulis}

Menurut Muhammad Ibnu Ibrahim Al Khatib (dalam Oktavia) yang menyebabkan pembelajaran imla' kurang maksimal diantaranya : Lemahnya pendengaran, penglihatan dan jari siswa, (2) Pelafalan kata yang kurang jelas dari pengajar, dan (3) Kurangya kemampuan siswa untuk membedakan huruf yang makhratnya berdekatan. Sementara pada faktor yang menyebabkan mengarang kurang baik adalah $:^{14}$ (1) Tidak sesuai antara kecenderungan siswa dengan materi yang diberikan, (2) Kurangnya motivasi untuk menulis, (3) Peran tradisional dari guru, yang terlalu banyak bicara saja, sehingga siswa bosan dan tidak adanya inovasi dalam menulis, sehingga materi ini berubah menjadi mencontoh dan bukan mengarang, (4) Pemilihan waktu yang kurang tepat untuk menulis ( pelajaran ini diteletakkan pada jam akhir), (5) Materi mengarang tidak berhubungan langsung dengan materi bahasa arab yang lain, membuat materi ini sedikit terdiskriminasi, dan (6) Sedikitnya tulisan dan merasa cukup dengan baris yang seikit dalam sebuah judul.

\section{Model Pembelajaran Kooperatif}

Pembelajaran kooperatif ialah kegiatan proses belajar mengajar yang dilakukan dengan cara berkelompok yang didalam kelompok tersebut siswa saling bekerja sama untuk saling membangun konsep, memecahkan masalah, menyelesaikan tugas-tugas yang diberikan guru atau melaksanakan sesuatu yang itu menjadi salah satu tujuan dari pembelajaran atau lainnya. ${ }^{15}$

Menurut suherman terdapat panduan yang harus dikerjakan agar pembelajaran koperatif dapat berjalan serta menjamin siswa mampu bekerja sama dengan siswa yang lain. Panduan tersebut diantaranya: Pertama, siswa yang tergabung dalam satu kelompok harus memiliki rasa bahwa mereka adalah bagian dari sebuah tim yang saling bekerja sama dalam mencapai tujuan yang harus dicapa secara bersama sama pula, dengan kata lain bahwa tujuan yang akan

13 Oktavia Ratnaningtyas, Pembelajaran Menulis Bahasa Arab di Program Khusus Perkuliahan Bahasa Arab (PKPBA) Universitas Islam Negeri Malang, Tafaqquh: Jurnal Penelitian dan Kajian Keislaman Volume 3, Nomor 2, Desember 2015, (Jombang: Institut Agama Islam Bani Fattah Jombang, 2015), h. 70.

صالح الشنطى، المهارات اللغوية مدخل إلى خصائص اللغة العربية فنوفا، (المملكة العربية 14

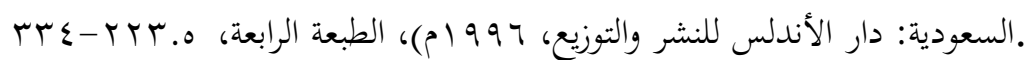

15 Helmiati, Model Pembelajaran, (Yogyakarta: Aswaja Pressindo, 2012) h. 36.

\section{'A Jami Jurnal Bahasa dan Sastra Arab}


dicapai bukunlah tujuan masing-masing individu secara pribadi. Kedua, siswa harus sadar bahwa permasalahan yang sedang dihadapi dalam proses pembelajaran merupakan masalah kelompok yang harus di selesaikan secara kelompok, sehingga masing-masing individu harus berkerja sama dan saling memiliki rasa tanggung jawab terhadap kelompoknya. Ketiga, para siswa harus menjalin interaksi dengan baik bersama anggota kelompoknya yang lain sehingga komunikasi dapat berjalan, serta mampu berdikusi bersama untuk menyelesaikan masalah yang sedang dihadapi. ${ }^{16}$

Saputra dan Rudyanto mengatakan terkait hakikat pembelajaran kooperatif dengan memberikan pengertian bahwa metode pembelajaran ini dan strategistrategi yang digunakannya merupakan satu dari beberapa bentuk pembelajaran gotong-royong yang memiki konsep seperti metode pembelajaran kelompok lainnya. $^{17}$

Namun pembelajaran kooperatif tidak bisa dilakukan secara asal-asalan seperti pembelajaran kelompok biasa. Dalam pembelajaran kooperatif masingmasing siswa memiliki tanggungjawab yang sama dalam membangun konsep belajar dan menghadapi masalah yang ada dalam kelompok untuk diselesaikan secara bersama-sama. Bukan dinamakan pembelajaran kooperatif apabila persoalan/masalah yang ada dalam kelompok hanya diselesai oleh satu orang tanpa melibatkan anggota kelompok yang lain.

Suprijono Roger dan David Johnson (2011) mengungkapkan bahwa tidak semua pembelajaran kelompok dapat disamakan dengan pembelajaran kooperatif, terdapat unsur-unsur yang harus ada didalam pembelajaran kooperatif sehingga pembelajaran dapat berjalan dengan baik dan sesuai dengan apa yang menjadi harapan pembelajaran. Unsur-unsur tersebut adalah $:^{18}$

1) Rasa saling ketergantungan antar peserta didik.

2) Masing-masing peserta didik harus nertanggung jawab kepada kelompoknya.

16 Erman Suherman, dkk, Strategi Pembelajaran Matematika Kontemporer, (Bandung: Universitas Pendidikan Indonesia, 2003), h.260.

17 Muhamad Afandi, Model dan Metode Pembelajaran di Sekolah, (Semarang: UNISSULA PRESS, 2013) h. 51

18 Agus suprijono, Cooperative Learning Teori \& Aplikasi PAIKEM (Yogyakarta: Pustaka Pelajar, 2011), h. 58.

\section{'A Jami Jurnal Bahasa dan Sastra Arab}

ISSN: 2252-9926 (Print), ISSN: 2657-2206 (Online) 
3) Peserta didik harus mampu berinteraksi dengan baik dengan peserta didik lainnya serta menjalin kerja sama dalam mencapai tujuan yang diharapkan.

4) Kemampuan komunikasi yang baik harus dimiliki oleh siswa sehingga dalam satu kelompok siswa tidak cenderung pasif.

5) Kelompok harus dikondisikan secara baik agar diskusi yang dilakukan dapat berjalan dan tujuan pembelajaran dapat terealisasi.

Kelompok pembelajaran kooperatif terdiri dari kelompok-kelompok kecil yang anggotanya 4-6 orang orang dengan struktur kempok yang heterogen. Perbedaan siswa dalam dalam konsep pembelajaran kooperatif meliputi perbedaan latarbelakang kemampuan akademik, jenis kelamin, perbedaan ras serta perbedaan-perbedaan lain yang dimiliki oleh masing-masing siswa. ${ }^{19}$

Bila dikaitkan dengan konsep sosial, pembelajaran kooperatif sangat cocok untuk diterapkan di Indonesia karena latar belakang bangsa yang terdiri keberagaman suku, budaya, ras dan agama. Dengan kata lain pembelajaran kooperatif dapat dijadikan sebagai salah satu wadah pemersatu bangsa Indonesia.

\section{a. Teams Games Turnament (TGT)}

Teams Games Turnaments merupakan pembelajaran yang beraliran kepada model pembelajaran kooperatif yang memiliki ciri khusus yaitu dilakukan dengan sistem kelompok dengan penyampaian dalam bentuk permainan-permainan akademik, adapun kelompok adalah terdiri dari semua siswa yang sedang mengikuti pembelajaran dengan tanpa membedakan latar belakang siswa. ${ }^{20}$

Pembelajaran ini mulai dikembangkan dan dikenalkan oleh Robert Slavin yang mulai membentuk kelompok-kelompok kecil sebagai teknik pembelajaran yang dilakukan, kemudian Salvin memaduhkan kelompok-kelompok tersebut dengan kompetensi tim dengan memberikan tugas-tugas akademik yang mampu merangsanng dan meningkatakan motivasi serta keaktifan siswa.

Secara umum Teams Games turnament sama dengan Student Teams Achievement Division (STAD). Dua jenis model pembelajaran ini memamg

19 Robert E. Slavin, Cooperative Learning, Teori, Riset dan Praktek, Terjemahan: Nurulita, (Bandung: Nusa Media, 2008), h. 163.

20 Agus suprijono, Cooperative Learning Teori \& Aplikasi PAIKEM (Yogyakarta: Pustaka Pelajar, 2011 ), h. 58.

\section{'A Jami Jurnal Bahasa dan Sastra Arab}


memiliki kesamaan pada langkah-langkah penerapannya. Namun yang membedakan adalah STAD menggunakan quis atau soal-soal yang dikerjakan individual sementara TGT menggunakan permainan-permainan akademik. ${ }^{21}$

Permainan akademik ini dimaksudkan untuk menjadikan proses pembelajaran dikelas menjadi menyenangkan dan dimaksudkan pula untuk menambah motivasi dari setiap siswa dalam mengikutinya. Permainan ini dibut oleh guru dengan menyesuaikan materi yang sedang dipelajari. Didalam permainan akedemik ini guru memberikan materi-materi yang harus dikuasi atau juga bisa digunakan sebagai bentuk evaluasi untuk mengetahui pencapain dari hasil belajar yang telah dilakukan.

Dalam TGT masing-masing individu memainkan permainan yang berkaitan dengan materi pembelajaran yang sedang dipelajari bersama anggota kelompoknya lain untuk menyumbangkan nilai terbaik kepada kelompoknya sehingga mampu menjadi kelompok yang terbaik. Terdapat 5 unsur dalam pembelajaran tgt yaitu, 1) penyajian kelas.(2) belajar kelompok.(3) permainan.(4) pertandingan dan(5) penghargaan kelompok. Dari komponen-komponen ini sehingga metode ini disebut Teams Games Tournament. ${ }^{22}$

Namun meskipun pembelajaran model TGT cukup efektif diterapkan, akan tetapi memang setiap model atau metode pembelajaran pasti memiliki kelebihan dan kekurangan. Seperti yang diungkapkan oleh Salvin bahwa terdapat beberapa kekurangan dan kelebihan dalam penggunaan TGT sebagai berikut $:^{.23}$

1) Kelebihan model TGT

a) Meningkatkan serta mengembangkan kemampuan berpikir dan menambah keterampilan secara kelompok.

b) Menghapus pandangan yang berbeda atau diskriminasi terhadap ras, agama, warna kulit yang melatar belakangi pribadi siswa.

c) Terdapat tutor sebaya yang mampu mengorganisi jalannya diskusi kelompok dan menjadi pembimbing bagi anggota kelompok.

21 Robert E. Slavin, Cooperative Learning, Teori, Riset dan Praktek, Terjemahan: Nurulita, (Bandung: Nusa Media, 2008), h. 164.

22 Yanto Rochmanto, Penerapan Model Pembelajaran Tgt (Team Games Tournament) Pada Mata Pelajaran Ips Kelas Viii Dengan Memanfaatkan Facebook Sebagai Media Pembelajaran (Semarang: Universitas Negeri Semarang, 2015), h. 15.

23 Salvin, Prosedur Penelitian Suatu Pendekatan Praktik (Jakarta: PT. Rineka Cipta, 2010), h. 142

\section{'A Jami Jurnal Bahasa dan Sastra Arab}


d) Meningkatkan interaksi antara siswa dengan siswa lain berimbas kepada adanya peningkatan aspek sosial dan kemampuan dalam menyampaikan pendapat kepapa temannya yang lain.

e) Memberikan keleluasaan kepada siswa untuk belajar dan berdikusi dengan temannya, berinteraksi, dan mencoba untuk meyelesaikan permasalahan-permasalahan dengan prinsip yang jujur dan bertanggung jawab.

f) Turnamen yang diikuti masing-masing kelompok menjadikan suasana kelas tidak monoton dan terkesan kaku yang menjadikan siswa menjadi bosan. Permainan-permainan yang diperlombakan dapat memberikan kesan menyenangkan kepada siswa sehingga dapat meningkatkan motivasinya dalam belajar

g) Meskipun pembelajaran kelompok, model pembelajaran ini tidak mengabaikan peran dan kontribusi masing-masing siswa. Hal ini karena masing-masing siswa berpengaruh terhadap peningkatan perolehan nilai kelompok dalam turnamen, sehingga siswa akan terus berusahan dengan giat mendapatkan nilai terbaik secara individu untuk kemudian disumbangkan serta dijadikan satu dengan nilai siswa lain dalam anggota kelompoknya.

2) Kekurangan model TGT

a) Siswa masih menganggap model pembelajaran ini asing dan belum terbiasa untuk melakukannya karena siswa telah terbiasa menggunakan model pembelajaran konvensional yang cukup hanya dengan mendengarkan ceramah saja. Untuk mengatasi hal tersebut menjadikan perlu adanya penjelasan yang yang dilakukan oleh guru sehingga cukup menghabiskan waktu dalam memulainya

b) Terdapat kesuliatan bagi seorang guru dalam mengawalinya, karena pembentukan kelompok cenderug menjadikan suasana kelas menjadi tidak kondusif dan sulit di kelola.

c) Waktu yang dipelukan cukup lama, dan tidak dapat dilakukan hanya dalam satu pertemuan.

\section{'A Jami Jurnal Bahasa dan Sastra Arab}




\section{b. Langkah-langkah Penerapan TGT dalam Pembelajaran Bahasa Arab}

Berdasarkan keterangan tyang telah disampaikan sebelumnya bahwa Langkah-langkah penerapan TGT dalam Pembelajaran dimulai dari $:^{24}$

1) Penyajian Kelas.

Pada awal pembelajaran guru memulai dengan menyampaikan materi pembelajaran yang sedang dipelajari saat itu, suatu contoh guru menyampaikan materi tentang maharah Al-Kitabah pada bab At-Ta'aruf (perkenalan). Dalam penyajian kelas guru dapat menggunakan motode pengajaran langsung seperti ceramah atau diskusi mengenai materi At-Ta'aruf (perkenalan) yang dipandu oleh guru. Pada tahapan ini siswa dengan seksama memperhatikan penjelasan dari guru secara Bersama-sama.

\section{2) Belajar Kelompok (Team)}

Setelah memberikan penyajian kelas terhadap materi yang sedang dipelajari, Langkah selangjutbya yaitu guru kelompok denhan cara membagi siswa kedalam kelompok-kelompok kecil yang beranggotakan dari 3-4 siswa yang bersifat beragam baik dari jenis kelamin, atau dari tingkat kemampuan siswa pada masing-masing kelompok. Tujuan pembentukan kelompok ini adalah agar siswa dapat mendiskusikan materi yang telah disampaikan oleh guru secara mendalam bersama anggota kelompoknya dan memotivasi serta membantu anggota kelompoknya yang mengalami kesulitan dalam memahami serta bekerja sama untuk dapat menjadikan kelompoknya menjadi kelompok yang terbaik dalam permainan yang akan dilakukan.

3) Permainan (Games)

Permainan atau game dirangcang oleh guru dengan memberikan pertanyaan-pertanyaan untuk menguji tingkat kefahaman siswa terhadap materi. Permainan dilakukan pada meja-meja yang secara khusus telah disiapkan. Terdapat tiga meja pertandingan, didalam masing-masing meja, telah siap masing-masing anggota kelompok yang bertanding. Suatu contoh dalam meja pertandingan A merupakan meja petandingan untuk menyusun jumlah mufidah dari kata acak yang telah disediakan. Di meja pertandingan B merupakan meja

24 Robert E. Slavin, Cooperative Learning, Teori, Riset dan Praktek, Terjemahan: Nurulita, (Bandung: Nusa Media, 2008), h. 163.

\section{'A Jami Jurnal Bahasa dan Sastra Arab}


petandingan untuk menentukan tarkib dari suatu jumlah mufidah yang telah diberikan. Dan pada meja $\mathrm{C}$ merupakan meja petandingan untuk Insya (mengarang) jumlah mufidah.

4) Pertandingan (Tournament)

Pertandingan dilakukan secara bertahap oleh guru pada setiap minggu, didalam turnament guru menentukan masing-masing anak yang bertanding pada setiap meja dengan melihat kinerja dari siswa yang terus dipantau oleh guru. Suatu contoh pada minggu pertama guru menenpatkan siswa pada meja $\mathrm{C}$ adalah Siswa yang mempunyai kinerja tinggi, Meja B adalah siswa yang mempunyai kinerja sedang dan meja A adalah siswa yang mempunyai kinerja rendah pada masing-masing kelompok. Untuk memberikan motivasi pada setiap pertandiangan siswa yang memperoleh nilai terbaik pada masing-masing meja akan di naikan ke meja yang dengan kemampuan kinerja yang lebih tinggi, begitu pula sebaliknya siswa yang memperoleh kemampuan yang nilai terendah akan diturunkan ke meja yang dengan kemampuan yang lebih rendah

5) Penghargaan Kelompok ( Team Recognition).

Penghargaan diberikan kepada salah kelompok yang meraih nilai paling tinggi dibandingkan kelompok-kelompok yang lain, nilai didapatkan setelah melalui semua permainan yang di pertandinngkan. Nilai yang didapatkan oleh masing-masing anggota kelompok akan di jumlahkan dan di jadikan nilai kelompok, dan kelompok yang mendapatkan nilai total paling tinggi adalah kelompok yang berhak mendapatkan hadiah dari guru.

\section{Hasil Penelitian}

Penelitian ini dilaksanakan di SMP Islam Sabilurrasyad Malang yang merupakan salah satu sekolah berbasis pesantren yang berada di Kota Malang Jawa Timur. Di sekolah ini memberikan pembelajaran bahasa Arab dilakukan pada semua siswa siswinya. Namun pada penelitian ini data diambil dari kelas VIII yang berjumlah 28 anak. Adapun permasalah dalam penelitian ini adalah kurang antusiasnya siswa dalam mengikuti pembelajaran maharah kitabah yang dikarenakan perbedaan karakteristik dan kemampuan masing-masing siswa dalam memahami materi maharah kitabah, sehingga perlu adanya alternatif model pembelajaran yang tepat digunakan untuk mengatasi permasalahan yang

\section{'A Jami Jurnal Bahasa dan Sastra Arab}


dihadapi dalam pembelajaran maharah kitabah di SMP Islam Sabilurrasyad Malang.

Data diambil melalui observasi dan wawancara mendalam kepada kepala sekolah, waka kurikulum, guru bahasa Arab dan siswa kelas VIII SMP Islam Sabilurrasyad serta pihak-pihak terkait. Data juga diperoleh dari dokumendokumen pembelajaran seperti silabus dan rencana pelaksanaan pembelajaran (RPP) yang dibuat oleh guru pengampu pembelajaran bahasa Arab.

Dari hasil wawancara kepada kepala sekolah dan waka kurikulum. Pembelajaran bahasa Arab pada sekolah ini merupakan perpaduan antara penerapan kurikulum nasional dengan kurikulum yayasan, dimana pada siswasiswi pada sekolah ini adalah siswa-siswi yang dipersiapkan sebagai generasi penerus dimasa depan yang menguasai bahasa asing dengan fokus penguasaan pada bahasa Arab serta panduan pelaksanaannya.

Namun pada pelaksanaannya muncul permasalahan-permasalahan yang menjadikan pembelajaran kurang efektif. Salah satu permasalahan yang muncul adalah kurangnya inovasi yang dilakukan oleh guru dalam menerakap model dan strategi pembelajaran serta menganggap bahwa metode ceramah masih relevan diterapkan pada pembelajaran bahasa Arab. Guru menyampaikan pembelajaran dengan mengikuti alur yang ada pada buku ajar. Setelah guru menjelaskan materi pembelajaran siswa berlatih dengan mengajakan soal-soal yang terdapat pada lembar kerja siswa. Berikut penuturan penuturan yang diberikan oleh guru:

Ketika pembelajaran bahasa Arab, saya mengajar dengan mengikuti panduan yang ada dalam buku ajar, biasanya saya memulai dengan membaca secara bersama-sama materi yang ada pada buku, kemudian saya mengartikannya kedalam bahasa Indonesia agar anak-anak bisa mengerti maknanya serta menulis di papan mufradat-mufradat baru yang penting. Setelah saya menjelaskan anakanak berlatih dengan mengerjakan soal-soal yang ada dalam buku, kemudian kita koreksi bersama-sama.

Pada pembelajaran maharah kitabah tentu tidak dapat dilakukan dengan hanya mendengarkan penjelasan guru kemudian mengerjakan soal-soal yang ada dalam buku ajar. Pembelajaran harus dilukan secara bertahap dengan diawali dengan mencontoh, mereproduksi apa yang didengar menjadi tulisan, menggabungkan berberapa kata menjadi sebuah kalimat dengan sususan yang

\section{'A Jami Jurnal Bahasa dan Sastra Arab}

ISSN: 2252-9926 (Print), ISSN: 2657-2206 (Online) 
benar, mengarang dengan mengikuti panduan hingga mengarang bebas. ${ }^{25}$ Semua tahapan tersebut harus dilakukan agar pembelajar maharah kitabah dapat berjalan efektif dengan hasil yang maksimal.

Permasalahan lain yang muncul adalah kondisi siswa yang heterogen dengan latar belakang kemampuan bahasa Arab yang beragam dan cenderung nampak adanya ketimpangan antar siswa. Permasalahan ini terjadi karena tidak semua siswa mempunyai minat dan motivasi untuk mengikuti pembelajaran. Untuk mengatasi permasalahan tersebut maka perlu adanya metode pembelajaran yang mampu mengakomodasi keberagaman peserta didik dengan menjadikan peserta didik yang mahir bebahasa Arab menjadi pendorong peserta didik lain yang memiliki kemampuan dibawahnya melalui kegiatan bersama secara kelompok. Pembelajaran juga harus didesain dengan menarik dan menyenangkan yang mampu memunculkan motivasi siswa untuk mengikutinya dengan antunsias.

Sebagai alternatif penyelesaian dari masalah ini, guru dapat menggunakan model pembelajaran Kooperatif Teams Games Turnaments (TGT) yang diterapkan pada Maharah Kitabah. Penerapan model pembelajaran ini dengan dibentuk kelompok-kelompok kecil yang terdiri dari 3-4 siswa pada masingmasing kelompok, maka dari 28 siswa terdapat 7 kelompok yang beranggotan 4 siswa pada masing-masing kelompok, dari 7 kelompok tersebut semua akan bersaing dan menjadikan kelompoknya sebagai kelompok yang terbaik melalui berbagai permainan yang telah disiapkan oleh guru.

Tujuan dibentuknya kelompok adalah sebagai upaya untuk mengatasi ketimpangan kemampuan terhadap Maharah Kiatabah yang dimiliki oleh siswa. Dalam satu kelompok guru telah menempatkan seorang siswa yang memiliki kemampuan diatas rata-rata siswa yang lain dengan maksud menjadikan anak tersebut sebagai tutor sebaya yang mampu memberikan bimbingan kepada anggota kelompok yang lain. Sementara tujuan dari adanya permainan akademik yang telah dibuat oleh guru adalah sebagai motivasi kepada siswa agar berantusias untuk mengikuti pembelajaran, tidak mengantuk dan tidak bosan, sehingga diharapakan hasil pembelajaran dapat maksimal.

25 Ahris Choiri Wafa, Problematika Pembelajaran Maharah al-Kitabah Siswa Kelas X MAN Tempel Sleman, ( Yogyakarta, 2004), h. 15-17

'A Jami Jurnal Bahasa dan Sastra Arab

ISSN: 2252-9926 (Print), ISSN: 2657-2206 (Online) 
Adapun bentuk permainan yang paling sederhana dan dapat dilaksanakan dengan media yang terbatas adalah sambung kata. Adapun cara bermainnya adalah dengan membariskan siswa pada masing-masing kelompok, setiap kelompok akan diberikan satu kata untuk didiskusikan bersama anggota kelompoknya. Dari kata tersebut masing-masing kelompok menyiapkan kalimat yang berkaitan dengan kata yang telah diberikan oleh guru. Kalimat yang disusun minimal terdiri dari empat suku kata, hal ini karena jumlah anggota kelompok adalah berjumlah empat orang. Setelah itu secara bergantian masing-masing siswa menulis satu kata pada bidang yang telah disiapkan dipapan tulis hingga semua siswa telah maju kedepan untuk menulis kata, cara ini bisa dilakukan sebanyak 3-4 kali. Adapun kelompok yang menang adalah kelompok yang paling cepat dan tepat dalam merangkai kata hingga menjadi kalimat.yang sempurna serta memperoleh nilai yang paling tinggi jika dibandingkan dengan nilai kelompok yang lain.

Model pembelajaran kooperatif Teams Games Turnament (TGT) dirasa tepat diterapkan sebagai alternatif model pembelajaran untuk mengatasi masalah ketimpangan kemampuan seorang siswa terhadap siswa lainnya dikarenakan model pembelajaran ini identik dengan cara belajar berkelompok. Antara siswa dengan siswa lainnya saling mendukung dan melengkapi kekurangan masingmasing sehingga mampu mengatasi perbedaan kemampuan yang dimiliki siswa. Model pembelajaran ini juga dirasa mampu meningkatkan antusias siswa karena penerapan model ini dilakukan dengan cara melakukan permainan akademik yang berkaitan dengan maharah kitabah dengan sistem perlombaan antar kelompok. Dengan permainan tersebut siswa akan merasa senang serta antusias mengikuti pembelajaran karena siswa tidak hanya pasif dengan mendengarkan penjelasan dari guru, melainkan siswa terlibat secara langsung dalam permainan tersebut dan berusaha bersama kelompoknya untuk menjadi juara dalam perlombaan yang dilakukannya

\section{Kesimpulan}

SMP Islam Sabilurrasyad sebagai sekolah yang memberikan pembelajaran maharah kitabah sebagai salah satu kemampuan yang harus dikuasai siswa yang belajar bahasa Arab memiliki tanggungjawab melaksanakan pembelajaran yang

\section{'A Jami Jurnal Bahasa dan Sastra Arab}


inovatif dan menarik sebagai upaya meningkatkan motivasi siswa dalam mengikuti pembelajaran. Kegiatan pembelajaran harus dilakukan dengan memahami permasalahan dan kebutuhan siswa sehingga tujuan pembelajaran tercapai secara maksimal. Dengan kondisi siswa yang heterogen dan kemampuan kitabah yang tidak merata, maka perlu adanya model pembelajaran yang mampu mengatasi permasalahan tersebut. Sebagai aternatif yang dapat dilakukan adalah menerapkan model pembelajaran kooperatif Teams Games Turnaments (TGT) yang merupakan salah satu jenis model pembelajaran. Model pembelajaran ini memiliki konsep pembejaran berkelompok yang menyenangkan dengan menjadikan permainan akademik sebagai upaya untuk meningkatkan motivasi belajar dan kemampuan peserta didik terhadap materi yang sedang dipelajari. Model pembelajaran ini sesuai untuk menjadi alternatif model pembelajaran bahasa Arab khususnya pada Maharah Kitabah yang selama ini dianggap sulit dan membosankan.

Tulisan ini memiliki kekurangan dari aspek penyajian data secara kuantitatif terkait hasil yang diperoleh siswa dalam penerapan model pembelajaran kooperatif Teams Games Turnaments dikarena pada penelitian ini dilakukan dengan cara kualitatif dengan menganalisis permasalahan yang dihadapi siswa dalam pembelajaran maharah kitabah. penelitian bertujuan untuk dapat dijadikan landasan penelitian lain yang mencari data secara kuantitatif dengan menguji keefektifan penerapan metode ini.

\section{Daftar Pustaka}

Afandi, Muhamad, Model dan Metode Pembelajaran di Sekolah, (Semarang: UNISSULA PRESS, 2013)

Efendy, Ahmad Fuad, Metode Pengajaran Bahasa Arab, (Malang: Misykat, 2004)

Fakhrurrozi, Aziz, dan Erta Mahyudin, Pembelajaran Bahasa Arab, (Cct II, Jakarta: Direktorat Jendral Pendidikan Islam, Kementrian Agama RI)

Hamid, Abdul, Mengukur Kemampuan Bahasa Arab untuk Studi Islam, (Malang: UIN Maliki Press, 2013)

Helmiati, Model Pembelajaran, (Yogyakarta: Aswaja Pressindo, 2012)

Hermawan, Acep, Metodologi Pembelajaran Bahasa Arab, (Cct IV; Bandung: PT Remaja Rosdakarya, 2014)

Jacobsen, David A., Methods for Teacing Metode-Metode Pengajaran Meningkatkan Belajar Peserta Didik TK-SMA, (Yogyakarta: Pustaka Pelajar, 2012)

Mulyono, Strategi Pembelajaran, (Malang : UIN-Maliki Press, 2012)

\section{'A Jami Jurnal Bahasa dan Sastra Arab}

ISSN: 2252-9926 (Print), ISSN: 2657-2206 (Online) 
Nurdyansyah, M. Musfiqon, Pendekatan Pembelajaran Saintifik, (Sidoarjo: Nizamia Learning Center, 2015)

Pratama, Bunga Chika, Model Pembelajaran Two Stay Two Stray Berbantu Media Puzzle Terhadap Hasil Belajar Di Tinjau Dari Gaya Belajar Siswa Jurnal Penelitian dan Pengembangan Pendidikan. Vol. 3 (2) pp. 84-88, (Semarang :PGSD, Universitas PGRI Semarang,2019)

Purwitasari, Anis, Keterampilan Guru Dalam memilih Strategi Pembelajaran Yang Sesuai Dengan Gaya Belajar Siswa Di MIM PK Kartasura, Naskah Publikasi Skripsi, (Surakarta: Universitas Muhammadiyah Surakarta, 2019)

Rahmania, Lady, Pengaruh Model Pembelajaran Kooperatif Tipe Tgt (Teams Games Tournament) Dengan Bantuan Question Card Terhadap Hasil Belajar Siswa Materi Persamaan Kuadrat Kelas X Di Sma Negeri 6 Kediri ( Kediri: Universitas Nusantara PGRI Kediri, 2017)

Ratnaningtyas, Oktavia, Pembelajaran Menulis Bahasa Arab di Program Khusus Perkuliahan Bahasa Arab (PKPBA) Universitas Islam Negeri Malang, Tafaqquh: Jurnal Penelitian dan Kajian Keislaman Volume 3, Nomor 2, Desember 2015, (Jombang: Institut Agama Islam Bani Fattah Jombang, 2015)

Robert E. Slavin, Cooperative Learning, Teori, Riset dan Praktek, Terjemahan: Nurulita, (Bandung: Nusa Media, 2008)

Rochmanto, Yanto, Penerapan Model Pembelajaran Tgt (Team Games Tournament) Pada Mata Pelajaran Ips Kelas Viii Dengan Memanfaatkan Facebook Sebagai Media Pembelajaran (Semarang : Universitas Negeri Semarang, 2015)

Rosyidah, Ainun dan Abdul Basid, Analisis Diagnostik Kesulitan Belajar Maharah al-Kitabah Mahasiswa Jurusan Bahasa dan Sastra Arab Angkatan 2015 UIN Maulana Malik Ibrahim Malang, ( Malang, 2017)

Salvin, Prosedur Penelitian Suatu Pendekatan Praktik (Jakarta: PT. Rineka Cipta, 2010)

Slameto, Belajar dan Faktor - Faktor Belajar yang Mempengaruhi, (Jakarta: Rineka Cipta, 1995)

Sudjana, Nana, Dasar-Dasar Proses Belajar Mengajar, (Bandung: Sinar Baru Algesindo, 1998)

Suherman, Erman, dkk, Strategi Pembelajaran Matematika Kontemporer, (Bandung: Universitas Pendidikan Indonesia, 2003)

Suprijono, Agus, Cooperative Learning Teori \& Aplikasi PAIKEM (Yogyakarta: Pustaka Pelajar, 2011)

Suprijono, Agus, Cooperative Learning Teori \& Aplikasi PAIKEM (Yogyakarta: Pustaka Pelajar, 2011 ), h. 58.

Tarigan, Henry Guntur, Menulis sebagai keterampilan berbahasa, (Bandung: Angkasa, 1994)

\section{'A Jami Jurnal Bahasa dan Sastra Arab}


Trianto, Model Pembelajaran Terpadu, Konsep, Strategi dan Implementasi dalam Kurikulum Tingkat Satuan Pendidikan (KTSP), (Jakarta: PT Bumi Aksara, 2012)

Trianto, Model-Model Pembelajaran Inovatif Berorientasi Konstruktivistik, (Jakarta: Prestasi Pustaka Publisher, 2011)

Trianto, Model-Model Pembelajaran Inovatif Berorientasi Konstruktivistik, (Jakarta: Prestasi Pustaka Publisher, 2011)

Umamah, M., \& Muassomah, M. Pembelajaran Daring Melalui Teknik Kolaboratif pada Keterampilan Menulis Peserta didik di SMA Darul Qur'an Kota Mojokerto. ALSUNIYAT: Jurnal Penelitian Bahasa, Sastra, dan Budaya Arab, 3(2), 88-100.

Wafa, Ahris Choiri, Problematika Pembelajaran Maharah al-Kitabah Siswa Kelas XMAN Tempel Sleman, ( Yogyakarta, 2004)

Wibowo, Dwi Cahyadi, Aspek-Aspek keterampilan dalam pendidikan bahasa, http:// DWI CAHYADI WIBOWO: aspek-aspek keterampilan dalam pendidikan bahasa. diakses pada 23 maret 2014

$$
\begin{aligned}
& \text { أحمد محمود عليان، المهارة اللغوية مهيّها وطروق التدرسها، ( رياض: دار المسلم، } 1999 \text { ) }
\end{aligned}
$$

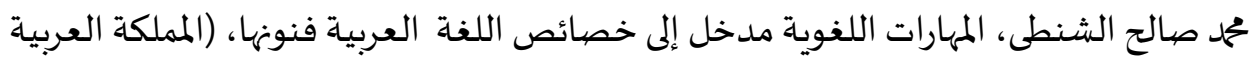

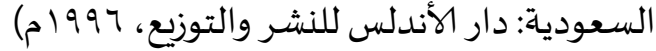

